\title{
Complete replacement of fish meal by other animal protein sources on growth performance of Clarias gariepinus fingerlings
}

\author{
Arnauld S. M. Djissou • Dogbè C. Adjahouinou - Shunsuke Koshio • \\ Emile D. Fiogbe
}

Received: 9 August 2016/Accepted: 3 October 2016/Published online: 12 October 2016

(C) The Author(s) 2016. This article is published with open access at Springerlink.com

\begin{abstract}
To completely replace the fish meal by a mixture of earthworm and maggot meals, experimental diets were tested during 42 days on Clarias gariepinus fingerlings. Five isoproteic and isoenergetic diets (40\% crude protein and $17.9 \pm 0.3 \mathrm{~kJ} \mathrm{~g}^{-1}$ ) including the control diet (D1) based on fish meal, were formulated. All these diets satisfied the essential amino acids requirements of $C$. gariepinus fingerlings. These diets were tested on triplicate groups of 50 fishes (initial body weight: $3 \pm 0.1 \mathrm{~g}$ ) bred in tank $\left(0.5 \mathrm{~m}^{3}\right)$. The approximate ratios 2:5; 1:4; 1:12 and 0:1 between the earthworm meal and the maggot meal were used, respectively, to formulate four diets D2, D3, D4 and D5 without fish meal. After the feeding period, significant differences $(P<0.05)$ were observed on growth, feed utilization between control diet (D1) and test diets (D2D5). Fish fed earthworm- and maggot-based diets were grown better than those fed the control diet. Survival and feed utilization were not significantly affected by the ratio between earthworm meal and maggot meal in the test diets. Lipid content was higher in carcass and fillet of fishes fed earthworm- and maggot meals-based diets than that of those fed fish meal-based diet. This study indicates that when the ratio 2:5 between the earthworm meal and the maggot meal is used to entirely replace fish meal and the ratio lysine/arginine of the diet is inferior to 1 , the growth performances and feed utilization of Clarias gariepinus fingerlings are improved.
\end{abstract}

Keywords Maggot $\cdot$ Earthworm $\cdot$ Growth performance $\cdot$ Feed utilization

\section{Introduction}

The nutrition is one of the most important factor to consider in fish farming, because it contributes up to $50 \%$ of fish production costs (Omoruwou and Edema 2011). Nowadays, it is necessary to increase fish production for satisfying the increasingly growing demand of protein. Therefore, fish breeding has been found necessary to increase fish production in order to make fish/protein available to the population. However, one of major constraints facing aquaculture is feeding. The prominence of fish meal in the production of animal feeds cannot be disputed but constitute the highest cost, thereby making the price of the feed to rise exponentially (Olaniyi and Salau 2013). In formulating nutritive diet for fish breeding, fish meal is used as the main dietary

\footnotetext{
A. S. M. Djissou $(\bowtie) \cdot$ D. C. Adjahouinou · E. D. Fiogbe

Laboratory of Research on Wetlands, LRZH/FAST/University of Abomey-Calavi, Abomey-Calavi, Benin

e-mail: arnauldb52@gmail.com

S. Koshio

Laboratory of Aquatic Animal Nutrition, Kagoshima University, Kagoshima, Japan
} 
protein source because of its nutritional quality and palatability properties (Hardy and Tacon 2002). It is, therefore, very crucial to find an alternative to replace fish meal to reduce fish feeding cost and halieutics resources pressure (Monebi and Ugwumba 2013).

Several studies attempted to substitute fish meal with other plant protein sources such as soybean or cottonseed meals in African catfish and vundu catfish (Imorou Toko et al. 2008), Lemna minor in common carp (Cyprinus carpio) fry (Yilmaz et al. 2004), Azolla nilotica in Oreochromis niloticus (Ebrahim et al. 2007) and animal protein sources such as earthworm in Heterobranchus longifilis (Sogbesan et al. 2007), Heteroclarias fingerlings (Monebi and Ugwumba 2013), maggot in Clarias anguillaris (Madu and Ufodike 2003) and Clarias gariepinus (Oyelese 2007), snail, termite, tadpole (Tacon and Metian 2008). In general, these studies showed that total replacement of fish meal leads to the decrease of feed intake, feed efficiency and growth performances. According to Imorou Toko et al. (2008), these results can be generally attributed to the removal of most antinutritional factors by various diets (heating, soaking, enzymes or amino acids supplementation, etc.).

Earthworm (Eisenia fetida) and maggot (Musca domestica) are animal protein sources with highly nutritive values (Sogbesan et al. 2006; Sogbesan and Ugwumba 2008). Also, they have high digestibility (NRC 2011) and good essential amino acids contents (Adesina 2012). These sources of animal proteins are less expensive and easy to produce using animal manures and/or agro-alimentary wastes (Sogbesan et al. 2006; Djissou et al. 2015). Therefore, they strongly contribute to reduce the cost of feed. The African catfish (Clarias gariepinus) is an omnivorous species with carnivorous tendency (Akete 2014), very rustic and appreciated, with strong economic potential and fast growth (Kareem and Ogunremi 2012).

In replacement of the fish meal, the proteinic sources must bring the ten essential amino acids (EAA) required for fishes (Médale et al. 2013). To satisfy the essential amino acids requirements for Clarias gariepinus fingerlings, the experimental diets without fish meal based on a mixture of earthworm and maggots (proteinic sources) were tested to determine their performances of growth and feed utilization on these Clarias gariepinus fingerlings.

\section{Methods}

Culture of the sources of animal protein and fish origin

The production of earthworm and maggots as well as artificial reproduction of Clarias gariepinus has been carried out at the experimentation station of the Laboratory of Research on Wetlands (University of AbomeyCalavi, Benin). Earthworms (Eisenia foetida) have been produced according to the method of Vodounnou et al. (2016), during 90 days (cycle of production of the earthworms) with ping dung substrate in 18 tanks. In each tank, $4 \mathrm{~kg}$ of substrate and $60 \mathrm{~g}$ of mature earthworms were sown. Maggots (Musca domestica) were produced according to Djissou et al. (2015) method with a mixture of soybean cake and chicken viscera substrate. Therefore, $3 \mathrm{~kg}$ of this substrate were put in 12 containers protected against solar rays and rain. Seven cycles of production of 3-4 days have been carried out in order to obtain the necessary quantity for the experimentation.

Earthworm and maggot meals manufacturing: at the end of the production period, the harvested earthworms and maggots were cleanly rinsed in water. Maggots were then boiled for $20 \mathrm{~min}$. These prepared earthworms and maggots were weighed and freeze-dried at $7{ }^{\circ} \mathrm{C}$ for $24 \mathrm{~h}$ in a lyophilisator (EYELA FDU-2110). They were again weighed after the drying operation, and then milled until to powder form using a milling apparatus. The obtained dried meals were packaged in airtight plastic bag and stored in fridge until use.

Fingerlings of Clarias gariepinus with initial body weight of $3 \pm 0.1 \mathrm{~g}$ were obtained 34 days after artificial reproduction which was implemented according to the method of Ducarme and Micha (2003).

Chemical analyses

The feed ingredients were analysed following AOAC (1990) procedures: crude protein was assessed by the Kjeldahl method after an acid digestion using Kjeltec 2300 Auto Analyser (Tecator Höganas, Sweden). The amino acids of feed ingredients were analysed with a Waters HPLC system (Waters 474, Waters, Milford, 
MA, USA) including two pumps (Model 515, Waters), an auto-sampler (Model 717, Waters), a fluorescence detector (Model 474, Waters) and a temperature control module. These amino acids analyses were done following the method previously described by Bosch et al. (2006). Thus, aminobutyric acid was added as an internal standard before hydrolyzation. Amino acids were derivatized with AQC (6-aminoquinolyl- $N$-hydroxysuccinimidyl carbamate) and then separated with a C-18 reverse-phase column Waters Acc. Tag $(150 \mathrm{~mm} \times 3.9 \mathrm{~mm})$. All of these analyses were conducted twice per sample in the Laboratory of Aquatic Animal nutrition of Kagoshima University (Japan).

Experimental diets

Based on the composition of essential amino acids and crude protein of the main ingredients used (Table 1), five experimental diets (D1-D5) were formulated varying the ratio (except control diet D1) between earthworm meal and maggot meal $(2: 5 ; 1: 4 ; 1: 12$ and $0: 1$, respectively) used for full replacement of fish meal (Table 2). Maggots are quantitatively more used in the feed formulation, because they are richer in amino acids than earthworms (Table 1). These ratios were adjusted not only to completely replace the fish meal but also to satisfy essential amino acids requirements of Clarias gariepinus fingerlings. The control diet (D1) was formulated with fish meal purchased from Ghana. All the formulated diets were isonitrogenous and isoenergetic (40\% protein and $17.9 \pm 0.3 \mathrm{~kJ} \mathrm{~g}^{-1}$ ) and approximately balanced in essential amino acids for Clarias gariepinus fingerlings requirements. Also, brewer's yeast, collected from Beninese society of brewery of Parakou (Benin), was used as complementary protein source to achieve dietary protein requirements of African catfish fingerlings. On the other hand, local palm oil was used as dietary lipid sources. Diets were manufactured by mixing the dry ingredients as described by Imorou Toko et al. (2007) for C. gariepinus fingerlings. The manufactured feeds were stored at $4{ }^{\circ} \mathrm{C}$ in airtight plastic bag until distribution.

Experimental procedure

The feeding trial was conducted during 6 weeks in re-circulated system including 15 tanks containing each $0.5 \mathrm{~m}^{3}$ of water supplied by a drilling and a compressor (FIAC, axair 100L 2CV 10B $230 \mathrm{~V}$ ) at a flow rate of 3 $\mathrm{L} \min ^{-1}$. Fifty fingerlings (initial mean weight, IBW: $3 \pm 0.1 \mathrm{~g}$ ) were stocked in each tank. Each dietary treatment was experimented in triplicate. To prevent fish death, each tank was covered at $50 \%$ with a mat for protecting fingerlings against sun rays.

The water quality parameters were monitored twice per week and remained throughout the trial within the acceptable range reported for the rearing of African catfish (Akinwole and Faturoti 2007). These parameters were not significantly different among the experimental tanks and varied from 27.6 to $28.5^{\circ} \mathrm{C}, 3.93$ to $4.48 \mathrm{mg} \mathrm{L}^{-1}$ and 4.72 to 5.02 for temperature, dissolved oxygen and $\mathrm{pH}$, respectively.

Table 1 Composition of essential amino acids (EAA) and crude protein (CP) of the main ingredients $\left(\mathrm{g} \mathrm{kg}^{-1} \mathrm{dry}\right.$ matter)

\begin{tabular}{|c|c|c|c|c|c|c|c|c|}
\hline EAA & $\begin{array}{l}\text { Fish } \\
\text { meal }\end{array}$ & $\begin{array}{l}\text { Rice } \\
\text { bran }\end{array}$ & $\begin{array}{l}\text { Soybean } \\
\text { meal }\end{array}$ & $\begin{array}{l}\text { Brewer's } \\
\text { yeast }\end{array}$ & $\begin{array}{l}\text { Cottonseed } \\
\text { meal }\end{array}$ & $\begin{array}{l}\text { Maize } \\
\text { bran }\end{array}$ & $\begin{array}{l}\text { Earthworm } \\
\text { meal }\end{array}$ & $\begin{array}{l}\text { Maggot } \\
\text { meal }\end{array}$ \\
\hline Thr & 23.1 & 0.5 & 7.6 & 24 & 4.5 & 2.0 & 17.6 & 20.9 \\
\hline Val & 27.7 & 1.0 & 5.6 & 28 & 5.0 & 2.0 & 13.2 & 19.1 \\
\hline Mét & 19.4 & 0.0 & 2.4 & 8 & 2.0 & 0.0 & 7.6 & 18.2 \\
\hline Ile & 24.5 & 0.5 & 5.2 & 23 & 25 & 1.0 & 11.6 & 30.5 \\
\hline Leu & 37.9 & 1.0 & 17.2 & 35 & 9.5 & 6.0 & 31.2 & 63.5 \\
\hline Phe & 37.4 & 1.0 & 13.6 & 21 & 11 & 4.0 & 18.4 & 35.3 \\
\hline His & 17.5 & 1.0 & 6.4 & 12 & 7 & 3.0 & 13.6 & 30.1 \\
\hline Trp & 5.7 & 1.4 & 3.2 & 7 & 4 & 1.0 & 1.2 & 31.7 \\
\hline Lys & 42.2 & 1.0 & 12 & 38 & 5 & 2.5 & 26.8 & 42.3 \\
\hline Arg & 34.3 & 2.9 & 20.4 & 26.0 & 21.5 & 5.0 & 28.4 & 60.6 \\
\hline $\mathrm{CP}$ & 662 & 48 & 324 & 500 & 303 & 103 & 569 & 584 \\
\hline
\end{tabular}


Table 2 Formulation and composition of experimental diets $\left(\mathrm{g} \mathrm{kg}^{-1}\right.$ dry matter)

\begin{tabular}{|c|c|c|c|c|c|}
\hline Ingredients & D1 & D2 & D3 & D4 & D5 \\
\hline Fish meal & 400 & 0 & 0 & 0 & 0 \\
\hline Rice bran & 50 & 50 & 50 & 50 & 50 \\
\hline Soybean meal & 250 & 250 & 250 & 250 & 250 \\
\hline Brewer's yeast & 0 & 50 & 50 & 50 & 50 \\
\hline Cottonseed meal & 150 & 150 & 150 & 150 & 150 \\
\hline Maize bran & 60 & 0 & 0 & 0 & 0 \\
\hline Earthworm meal & 0 & 120 & 80 & 32 & 0 \\
\hline Maggot meal & 0 & 305 & 343 & 390 & 421 \\
\hline Palm oil & 30 & 30 & 30 & 30 & 30 \\
\hline Vitamin $\operatorname{mix}^{\mathrm{a}}$ & 5 & 10 & 10 & 10 & 10 \\
\hline Mineral mix ${ }^{b}$ & 5 & 10 & 10 & 10 & 10 \\
\hline Starch & 50 & 20 & 22 & 23 & 24 \\
\hline Methionine & 0 & 5 & 5 & 5 & 5 \\
\hline Crude protein & 40.0 & 40.0 & 40.0 & 40.0 & 40.0 \\
\hline Ratio $^{c}$ & - & $2: 5$ & $1: 4$ & $1: 12$ & $0: 1$ \\
\hline Gross energy $\left(\mathrm{kJ} \mathrm{g}^{-1} \text { dry matter }\right)^{\mathrm{d}}$ & 18.2 & 18.7 & 17.9 & 18.0 & 17.6 \\
\hline Diet cost $\left(\$ \mathrm{~kg}^{-1}\right)^{\mathrm{e}}$ & 0.779 & 0.396 & 0.391 & 0.386 & 0.387 \\
\hline
\end{tabular}

${ }^{a}$ Vitamin premix contains (g $100 \mathrm{~g}^{-1}$ of premix): ascorbic acid, 50.0; D-calcium pantothenate, 5.0; choline chloride, 100.0; inositol, 5.0; menadione, 2.0; niacin, 5.0; pyridoxine $\mathrm{HCl}$, 1.0; riboflavin, 3.0; thiamin $\mathrm{HCl}$, 0.5; DL-alpha-tocopherol acetate $\left(250 \mathrm{IU} \mathrm{g}^{-1}\right), 8.0$; vitamin A acetate $\left(20,000 \mathrm{IU} \mathrm{g}^{-1}\right), 5.0$; vitamin micro-mix, 10.0; cellulose, 805.5. Vitamin micro-mix contains ( $\mathrm{g} \mathrm{kg}^{-1}$ of micro-mix): biotin, 0.5 ; cholecalciferol $(1 \mu \mathrm{g}=40 \mathrm{IU}), 0.02$; folic acid, 1.8; vitamin $\mathrm{B}_{12}, 0.02$; cellulose, 97.66

b Mineral premix contains ( $\mathrm{g} \mathrm{kg}^{-1}$ of premix): calcium phosphate (monobasic) monohydrate, 136.0; calcium lactate pentahydrate, 348.49; ferrous sulfate heptahydrate, 5.0; magnesium sulfate heptahydrate, 132.0; potassium phosphate (dibasic), 240.0; sodium phosphate (monobasic) monohydrate, 88.0; sodium chloride, 45.0; aluminum chloride hexahydrate, 0.15 ; potassium iodide, 0.15 ; cupric sulfate pentahydrate, 0.50 ; manganese sulfate monohydrate, 0.70 ; cobalt chloride hexahydrate, 1.0 ; zinc sulfate heptahydrate, 3.0; sodium selenite, 0.011

${ }^{c}$ Ratio earthworm meal:maggot meal

${ }^{\mathrm{d}}$ Gross energy was calculated on the basis of $23.7 \mathrm{~kJ} \mathrm{~g}_{\text {protein }}^{-1}, 39.5 \mathrm{~kJ} \mathrm{~g}_{\text {lipid }}^{-1}$ and $17.2 \mathrm{~kJ} \mathrm{~g}_{\text {carbohydrate }}^{-1}$

${ }^{\mathrm{e}}$ Prices in \$ (USD); $1 \$$ (USD) = 583.54 FCFA (UEMOA), based on 2016 (September) exchange prices. Labour and processing costs were included by adding $20 \%$ of the ingredients costs (Azaza et al. 2006)

Fish were hand-fed three times daily (08.00 AM, 01.00 and $06.00 \mathrm{PM})$ and during 6 days per week. The daily ration was fixed at $5 \%$ according to reports of Fiogbé and Kestemont (2003). At the seventh day of each week, the total number of surviving fishes in each tank was counted and fish biomass was determined to adjust the daily ration.

Growth performance and feed efficiency

Growth performances and diet nutrient utilization were analysed using the feed conversion ratio (FCR), specific growth rate (SGR), protein efficiency ratio (PER), percentage weight gain (PWG), survival rate (SR) and protein productive value (PPV). These parameters were calculated using the following formulae:

$$
\mathrm{FCR}=\frac{\text { Dry matter feed intake }(\mathrm{g})}{\text { Body mass gain }(\mathrm{g})}
$$

$$
\operatorname{SGR}(\%)=100 \times \frac{(\ln [\mathrm{FBW}]-\ln [\mathrm{IBW}])}{\text { Number of days }}
$$

where IBW and FBW are initial body weight and final body weight. 


$$
\begin{gathered}
\text { PER }=\frac{\text { Wet body mass gain }}{\text { Protein intake }} \\
\text { SR }(\%)=100 \times \frac{\text { Final number of fish }}{\text { Initial number of fish }} \\
\text { PWG }(\%)=100 \times \frac{\text { Mean weight gain }(\mathrm{g})}{\text { Initial mean weight }(\mathrm{g})} \\
\text { PPV }=\frac{\text { Body protein gain }}{\text { Protein intake }}
\end{gathered}
$$

Taking into account that the feed cost depends on the maggots and earthworms meals' content, we calculated the cost of feed required to produce $1 \mathrm{~kg}$ of biomass. The economic conversion ratio (ECR) was calculated with the following equation:

$$
\mathrm{ECR}=\text { Feed cost } \times \text { FCR }
$$

The cost of each experimental feed was determined on the basis of the cost of the ingredients used for its manufacturing.

\section{Statistical analysis}

Data obtained from the experiment were subjected to one-way analysis of variance after verifying the normality and the homogeneity of variance using the statistical software Statviews (version 5.01). Least-significant-difference test of Fisher was used to compare differences among individual means. Treatment effects were considered significant at $P<0.05$

\section{Results}

The composition (crude protein and amino acids profile) of ingredients is shown in Table 1. All the experimental diets satisfied the requirements of essential amino acids for African catfish fingerlings except valine in D2 (Table 3). The ratio lysine/arginine was lower than 1 in all the formulated diets except the control diet D1.

The data on growth, survival and feed utilization are presented in Table 4. It is generally noteworthy that earthworm- and maggot-based diets increased, significantly, growth performances of $C$. gariepinus much

Table 3 Calculated amino acid composition of the diets used in the trial $\left(\mathrm{g} \mathrm{kg}^{-1}\right.$ of diet)

\begin{tabular}{lcccccr}
\hline Essential amino acids & D1 & D2 & D3 & D4 & D5 & Requirement $^{*}$ \\
\hline Threonine & 17 & 8 & 12 & 13 & 13 & $5-5.6$ \\
Valine & 19 & 7 & 11 & 11 & 12 & $7.1-8.4$ \\
Methionine & 12 & 9 & 13 & 14 & 14 & $6-6.4$ \\
Isoleucine & 18 & 11 & 18 & 18 & 19 & $6-7.3$ \\
Leucine & 29 & 19 & 32 & 33 & 34 & $8-9.8$ \\
Phenylalanine & 25 & 13 & 20 & 21 & 21 & $12-14$ \\
Histidine & 14 & 9 & 15 & 15 & 16 & $4-4.2$ \\
Tryptophan & 5 & 6 & 13 & 14 & 15 & $1.2-14$ \\
Lysine & 34 & 14 & 22 & 23 & 24 & $12-14.3$ \\
Arginine & 30 & 20 & 33 & 34 & 35 & $10-12$ \\
\hline
\end{tabular}

* Essential amino acid requirements of Clarias gariepinus according to NRC (1993, 2011) 
Table 4 Growth performance and feed utilization of C. gariepinus fingerlings fed with the experimental diets

\begin{tabular}{lccccc}
\hline Parameters & \multicolumn{1}{c}{ D1 } & \multicolumn{1}{c}{ D2 } & \multicolumn{1}{c}{ D3 } & D4 & D5 \\
\hline IBW $(\mathrm{g})$ & $3.01 \pm 0.01$ & $3.01 \pm 0.012$ & $3.01 \pm 0.01$ & $3.01 \pm 0.01$ & $3.01 \pm 0.04$ \\
FBW $(\mathrm{g})$ & $12.49 \pm 2.88^{\mathrm{a}}$ & $24.66 \pm 1.78^{\mathrm{b}}$ & $22.02 \pm 2.16^{\mathrm{b}}$ & $22.12 \pm 1.27^{\mathrm{b}}$ & $21.03 \pm 1.14^{\mathrm{b}}$ \\
FCR & $2.03 \pm 0.43^{\mathrm{b}}$ & $1.06 \pm 0.02^{\mathrm{a}}$ & $1.18 \pm 0.06^{\mathrm{a}}$ & $1.08 \pm 0.03^{\mathrm{a}}$ & $1.01 \pm 0.03^{\mathrm{a}}$ \\
SGR & $3.25 \pm 0.53^{\mathrm{a}}$ & $4.97 \pm 0.17^{\mathrm{b}}$ & $4.69 \pm 0.23^{\mathrm{b}}$ & $4.72 \pm 0.14^{\mathrm{b}}$ & $4.59 \pm 0.13^{\mathrm{b}}$ \\
PER & $1.16 \pm 0.16^{\mathrm{a}}$ & $2.35 \pm 0.03^{\mathrm{b}}$ & $2.13 \pm 0.11^{\mathrm{b}}$ & $2.31 \pm 0.06^{\mathrm{b}}$ & $2.47 \pm 0.06^{\mathrm{b}}$ \\
SR (\%) & $93 \pm 0.0$ & $95.83 \pm 5.46$ & $94.16 \pm 8.82$ & $91.66 \pm 7.41$ & $97.67 \pm 0.83$ \\
PWG & $413.82 \pm 95.22^{\mathrm{a}}$ & $819.05 \pm 63.04^{\mathrm{b}}$ & $731.51 \pm 74.59^{\mathrm{b}}$ & $732.98 \pm 39.78^{\mathrm{b}}$ & $696.91 \pm 37.31^{\mathrm{b}}$ \\
PPV & $0.32 \pm 0.11$ & $0.39 \pm 0.06$ & $0.35 \pm 0.03$ & $0.34 \pm 0.02$ & $0.38 \pm 0.05$ \\
ECR & $1.58 \pm 0.04^{\mathrm{b}}$ & $0.42 \pm 0.03^{\mathrm{a}}$ & $0.46 \pm 0.01^{\mathrm{a}}$ & $0.42 \pm 0.02^{\mathrm{a}}$ & $0.39 \pm 0.03^{\mathrm{a}}$ \\
\hline
\end{tabular}

Mean \pm SD values in the same line followed by the same superscript are not significantly different $(P>0.05)$

more than control diet. However, it is suitable to notice that the highest earthworm/maggot ratio in the test diet (D2) produced the best fingerlings SGR $\left(4.97 \% \mathrm{day}^{-1}\right)$, and this growth factor decreased proportionally, but not significantly, with the highest ones (D3-D5) until $4.59 \%$ day $^{-1}$ while the diet D1-based fish meal has the lowest SGR (3.25\%). Furthermore, the final mean body weight (FBW) of fishes fed earthworm- and maggotbased diets started to deviate significantly after the third week of rearing from that of fish fed fish meal based diet D1 (Fig. 1).

Growth performances and feed utilization parameters such as SGR, FCR, PER and PPV were not significantly affected $(P>0.05)$ by ratio level among earthworm and maggot meals. But these parameters' values were significantly different $(P<0.05)$ between control diet and test diets except PPV. The proximate composition of the whole fish body is given in Table 5. Protein and lipid contents of the fishes increased significantly for all dietary treatments. However, the highest protein gain was noticed for fishes fed diet 2 while that of lipid gain was produced by diets 2 and 4 .

Feed costs decreased significantly with total replacement of fish meal in diets (Table 2). ECR followed the same trend as feed costs, but it did not change significantly with the variation of ratio earthworm/maggot (Table 4).

\section{Discussion}

The crude protein percentage of diets tested in this study (40\%) is close to the range of the optimum protein requirement of catfishes (Clarias gariepinus, Heterobranchus bidorsalis and Heteroclarias) which fluctuate among 40 and $42.5 \%$ (Fagbenro et al. 1992; Eyo 1996; Monebi and Ugwumba 2013). Several studies showed that the total replacement of fish meal by maggot or earthworm meal solely results in the reducing growth performances of some catfishes such as Heterobranchus longifilis (Sogbesan et al. 2007), Heteroclarias fingerlings (Monebi and Ugwumba 2013), Clarias anguillaris (Madu and Ufodike 2003), and Clarias gariepinus (Oyelese 2007). Collins et al. (2013) reported that a mixture of the proteic sources in the replacement of fish meal improves the growth performances of fishes. The combination of unconventional animal protein sources as earthworm and maggot with different ratios was used in this study to satisfy in diets, the protein and amino acid requirements of reared Clarias gariepinus fingerlings. Furthermore, when the feed

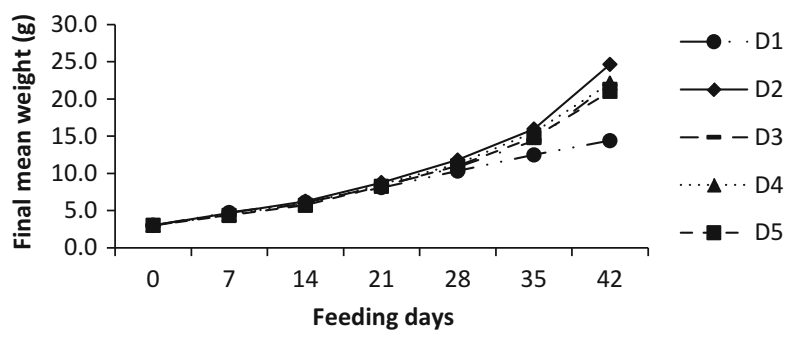

Fig. 1 Growth performance of fish C. gariepinus fingerlings fed experimental diets 
Table 5 Proximate composition of $C$. gariepinus fingerlings fed experimental diets

\begin{tabular}{lllllcc}
\hline Composition (\% dry weight) & Initial & D1 & D2 & D3 & D4 & D5 \\
\hline Dry matter & $23.4 \pm 0.3$ & $26.6 \pm 0.25$ & $29.7 \pm 0.22$ & $28.5 \pm 0.77$ & $29 \pm 0.83$ & $28.7 \pm 0.28$ \\
Protein & $13.1 \pm 0.1$ & $15.2 \pm 0.55^{\mathrm{a}}$ & $15.9 \pm 0.04^{\mathrm{b}}$ & $15.3 \pm 0.31^{\mathrm{ab}}$ & $15.6 \pm 0.27^{\mathrm{ab}}$ & $15.5 \pm 0.09^{\mathrm{ab}}$ \\
Lipid & $4.3 \pm 0.13$ & $7.5 \pm 0.40^{\mathrm{a}}$ & $9.2 \pm 0.25^{\mathrm{b}}$ & $8.3 \pm 0.36^{\mathrm{ab}}$ & $9.3 \pm 0.5^{\mathrm{b}}$ & $7.4 \pm 0.16^{\mathrm{a}}$ \\
Ash & $2.9 \pm 0.31$ & $3.5 \pm 0.23$ & $3.5 \pm 0.28$ & $3.1 \pm 0.17$ & $3.1 \pm 0.07$ & $4 \pm 0.15$
\end{tabular}

Mean \pm SD values in the same line followed by the same superscript are not significantly different $(P>0.05)$

contribution in amino acids does not meet perfectly the needs for the animal, nitrogenized catabolism increases contributing to the aquatic environment pollution, the proteinic retention is consequently reduced, and thus, the growth is slowed down (Médale and Kaushik 2009).

The results showed that the total replacement of fish meal by combination of earthworm and maggot meals in Clarias gariepinus fingerlings feeding improved their growth performances and feed utilization. The highest growth performances and feed utilization were obtained with the diet 2 containing the highest earthworm/maggot ratio (2:5). Progressive increment in PWG was observed with increasing ratio between earthworm and maggot meals. The fish meal-based diet (D1) produced the lowest growth rate which may be attributed to its low feed efficiency. Moreover, this low growth could be due not only to the quality of the fish meal used but also to the high ratio between lysine and arginine in control diet (D1).

According to Massumotu et al. (1996) and Sogbesan et al. (2006), the biological value of protein source depends on its amino acid profile as well as its digestibility. The good FCR and PER values obtained for $C$. gariepinus fingerlings fed diets devoid of fish meal (D2-D5) are enabled by the unconventional animal protein sources used (earthworms and maggots) which are rich in essential amino acids (Adesina 2012). PER and FCR are also generally related to digestibility of nutrients (Jabir et al. 2012).

Fish survival was not affected by experimental diets. The high survival rates recorded indicate that feeding C. gariepinus fingerlings with earthworm- and maggot-based diets could enhance their survivorship. This is made possible because $C$. gariepinus is an omnivorous fish species which used efficiently animal protein source to cover energy requirements (NRC 2011). Moreover, these results indicate that the protein quality of feed formulated with unconventional animal protein source ingredient was well accepted by the fish.

An optimal EAA profile is a requisite for fish growth and nitrogen retention (Luo et al. 2006; Peres and Oliva-Teles 2009). All the experimental diets in the current trial are of high protein quality (Oyelese 2007), because each of them contains all the EAA with values higher than the requirement except valine in diet 2 . The difference of growth observed among the dietary treatments can be due to the lysine and methionine rates (1.4 and 0.9 , respectively) which were more close to the $C$. gariepinus fingerlings requirements in the diet 2 than in the other diets. As a matter of fact, lysine and methionine are the first limiting EAA in many fish diets (Mai et al. 2006) mainly in those based on unconventional of proteins sources (Médale and Kaushik 2009). Also, lysine is one of the amino acids involved in growth processes ( $\mathrm{Li}$ et al. 2009) and known to interact antagonistically with arginine (Cabral et al. 2013) by increasing the activity of the arginase and, consequently, arginine requirement (Kestemont 2007). Its low rate in diet 2 (inferior 1) comparatively to the other diets explains, therefore, clearly the best growth performance registered. Likewise, the best growth recorded with diet 2 can also be justified by the rate perfectly within the requirement range of phenylalanine (NRC 1993), an amino acid able to enhance channel catfish growth performance (Garg 2007).

On the other hand, the lowering effect noticed for the earthworm meal/maggot meal ratio of the diets, may be due to the EAA composition of maggot meal which is higher than that of earthworm meal. The increasing incorporation of maggot meal in experimental diets raised, progressively, its EAA composition exceeding the fingerlings requirements.

The results indicate that $C$. gariepinus fingerlings, can effectively utilize diets with combination of earthworm and maggot meals used for the entirely replacement of fish meal, without affected their survivability. The best growth performances and feed utilization were recorded with diets manufactured without fish meal which lysine/arginine ratio was inferior to 1 . On the other hand, these diets enabled the reduction of ECR from $70 \%$ (D3) to $75 \%$ (D5) approximately (versus control diet D1). This is due to the low production cost of earthworm and maggot meals which is about 61 and $76 \%$ of the cost of fish meal, respectively. Although no 
significant difference was noticed among the growth performances and ECR induced by experimental diets (D2-D5), the diet D2 with a ratio 2:5 between earthworm and maggot may be considered the most efficient.

The use of unconventional sources of proteins such as earthworm and maggot reduces the diets cost and improves the production of $C$. gariepinus.

Acknowledgments Financial support was provided by Japan International Cooperation Agency (JICA) through Laboratory of Aquatic Animal Nutrition, Kagoshima University, Japan.

Open Access This article is distributed under the terms of the Creative Commons Attribution 4.0 International License (http:// creativecommons.org/licenses/by/4.0/), which permits unrestricted use, distribution, and reproduction in any medium, provided you give appropriate credit to the original author(s) and the source, provide a link to the Creative Commons license, and indicate if changes were made.

\section{References}

Adesina AJ (2012) Comparability of the proximate and amino acids composition of maggot meal, earthworm meal and soybean meal for use as feedstuffs and feed formulations. Elixir Appl Biol 51:10693-10699

Akete AA (2014) Etude du régime alimentaire de Clarias gariepinus (Burchell, 1822). Editions universitaires européennes, ISBN10: 3841735207 , pp 52

Akinwole AO, Faturoti EO (2007) Biological performance of African catfish (Clarias gariepinus) cultured in recirculating system in Ibadan. Aquac Eng 36:18-23

AOAC (1990) Official methods of analysis, 15th edn. Association of Official Analytical Chemists, Arlington, p 1298

Azaza MS, Mensi F, Imorou Toko I, Dhraief MN, Abdelmouleh A, Brini B, Krä̈em MM (2006) Effets de l'incorporation de la farine de tomate dans l'alimentation du tilapia du Nil (Oreochromis niloticus L., 1758) en élevage dans les eaux géothermales du sud tunisien. Bull Inst Nat Sci Technol Mer 33:41-52

Bosch L, Alegria A, Farré R (2006) Application of the 6-aminoquinolyl- $N$-hydroxysuccinimidyl carbamate (AQC), reagent to the RP-HPLC determination of amino acids in infant foods. J Chromatogr B Anal Technol Biomed Life Sci 831:176-178

Cabral EM, Fernandes TJR, Campos SD, Castro-Cunha M, Oliveira MBPP, Cunha LM, Valente LMP (2013) Replacement of fish meal by plant protein sources up to $75 \%$ induces good growth performance without affecting flesh quality in ongrowing Senegalese sole. Aquaculture 383:130-138

Collins SA, Overland M, Skrede A, Drew MD (2013) Effect of plant protein sources on growth rate in salmonids: meta-analysis of dietary inclusion of soybean, pea and canola/rapeseed meals and protein concentrates. Aquac 400:85-100

Djissou ASM, Tossavi EC, Vodounnou JD, Toguyeni A, Fiogbé ED (2015) Valorization of agro-alimentary waste for a production of maggots like source of proteins in the animal feeds. Int J Agron Agric Res. 7(6):42-46

Ducarme C, Micha J-C (2003) Technique de production intensive du poisson chat africain, Clarias gariepinus. Tropicultura 21(4):189-198

Ebrahim MSM, Zeinhom MM, Abou-Seif RA (2007) Response of Nile Tilapia (Oreochromis niloticus) fingerlings to diets containing Azolla meal as source of protein. J Arab Aquac Soc 2(1):54-69

Eyo AA (1996) Feed formulation and feeding practices in fish culture. Fish Feed Formulation National Institute for Freshwater Fisheries Research (NIFFR) extension guide series no. 4. In: Collaboration with German Technical Cooperation Agency (GTZ) and National Agricultural Research Extension and Liaison Services (NARELS)

Fagbenro OA, Balogun AM, Anyanwu CN (1992) Optimal dietary level for Heterobranchus bidorsalis fingerlings fed compounded diets. Nig J Appl Fish Hydrobiol. 1:41-45

Fiogbé ED, Kestemont P (2003) Optimum daily ration for Eurasian perch Perca fluviatilis L. reared at its optimum growing temperature. Aquac 216:243-252

Garg SK (2007) Effect of oral administration of 1-thyroxine (T4) on growth performance, digestibility, and nutrient retention in Channa punctatus (Bloch) and Heteropneustes fossilis (Bloch). Fish Biochem Physiol 33:347-358

Hardy RW, Tacon AGJ (2002) Fish meal: historical uses, production trends and future outlook for sustainable supplies. In: Stickney RR, McVey JP (eds) Responsible marine aquaculture. CAB International, Oxon, pp 311-325

Imorou Toko I, Fiogbe ED, Koukpode B, Kestemont P (2007) Rearing of African catfish (Clarias gariepinus) and vundu catfish (Heterobranchus longifilis) in traditional fish ponds (whedos): effect of stocking density on growth, production and body composition. Aquaculture 262:65-72

Imorou Toko I, Fiogbe ED, Kestemont P (2008) Mineral statuts of African catfish (Clarias gariepinus) fed diets containing graded levels of soybean or cottonseed meals. Aquaculture 275:298-305

Jabir MDAR, Razack SA, Vikineswary S (2012) Nutritive potential and utilization of super worm (Zophobas morio) meal in the diet of Nile tilapia (Oreochromis niloticus) juvenile. Afr J Biotechnol 11(24):6592-6598

Kareem AO, Ogunremi JB (2012) Growth performance of Clarias gariepinus fed compounded rations and maggots. J Environ Issues Agric Dev Ctries 4(1):1-5

Kestemont P (2007) Alimentation et nutrition des poissons. Master Complémentaire en Aquaculture. CUD-ULg-FUNDP, pp 163

Li P, Mai K, Trushenski J, Wu G (2009) New developments in fish amino acid nutrition: towards functional and environmentally oriented aquafeeds. Amino Acids 37:43-53

Luo L, Xue M, Cai XF, Cao XF, Liang HN (2006) Partially or totally replacement of fish meal by solvent-extracted cottonseed meal in diets for juvenile rainbow trout (Oncorhynchus mykiss). Aquac Nutr 12:418-424 
Madu CT, Ufodike EBC (2003) Growth and survival of catfish (Clarias anguillaris) juveniles fed live Tilapia and maggot as unconventional diets. J Aquat Sci 18(1):47-52

Mai K, Wan J, Ai Q, Xu W, Liufu Z, Zhang L, Zhang C, Li H (2006) Dietary methionine requirement of juvenile yellow croaker Pseudosciaena crocea $\mathrm{R}$. Aquaculture 251:564-572

Massumotu T, Ruchmat T, Ito Y (1996) Amino acid availability value for several protein sources for yellow tail (Seriola quinqueradiate). Aquaculture 146:109-119

Médale F, Kaushik S (2009) Les sources protéiques dans les aliments pour les poissons d'élevage. Cah Agric. 18:103-111

Médale F, Le Boucher R, Dupont-Nivet M, Quillet E, Aubin J, Anserat J (2013) Des aliments à base de végétaux pour les poissons d'élevage. INRA Prod Anim 26(4):303-316

Monebi CO, Ugwumba AAA (2013) Utilization of earthworm, Eudrilus eugeniae in the diet of Heteroclarias fingerlings. Int J Fish Aquac 5(2):19-25

NRC Nutrient requirements of fish (1993) National Academy Press, Washington, D.C., pp 105

NRC Nutrient requirements of fish (2011) National Academy Press Washington, D.C., pp 405

Olaniyi CO, Salau BR (2013) Utilization of maggot meal in the nutrition of African cat fish. Afr J Agric Res 8(37):4604-4607

Omoruwou PE, Edema CU (2011) Growth response of heteroclarias hybrid fingerlings fed on maggot based diet. Niger J Agric Food Environ 7(1):58-62

Oyelese OA (2007) Utilization of compounded ration and maggot in the diet of Clarias gariepinus. Res J Appl Sci 2(3):301-306

Peres H, Oliva-Teles A (2009) The optimum dietary essential amino acid profile for gilthead seabream (Sparus aurata) juveniles. Aquaculture 296:81-86

Sogbesan OA, Ugwumba AAA (2008) Nutritional values of some non-conventional animal protein feedstuffs used as fishmeal supplement in aquaculture practices in Nigeria. Turk J Fish Aquat Sci 8:159-164

Sogbesan OA, Ajuonu N, Musa BO, Adewole AM (2006) Harvesting techniques and evaluation of maggot meal as animal dietary protein source "Heteroclarias"' in outdoor concrete tanks. World J Agric Sci 2(4):394-402

Sogbesan OA, Ugwumba AAA, Madu CT, Eze SS, Isa J (2007) Culture and utilization of earthworm as animal protein supplement in the diet of Heterobranchus longifilis fingerlings. J Fish Aquat Sci 2:375-386

Tacon AGJ, Metian M (2008) Global overview on the use of fish meal and fish oil in industrially compounded aquafeeds: trends and future prospects. Aquaculture 285:146-158

Vodounnou DSJV, Kpogue DNS, Tossavi CE, Mensah GA, Fiogbe ED (2016) Effect of animal waste and vegetable compost on production and growth of earthworm (Eisenia fetida) during vermiculture. Int J Recycl Org Waste Agric. doi:10.1007/ s40093-016-0119-5

Yilmaz E, Akyurt I, Gunal G (2004) Use of duckweed, Lemna minor, as a protein feedstuff in practical diets for Common Carp, Cyprinus carpio, fry. Turk J Fish Aquat Sci 4:105-109 